\title{
The Purposes and Principles of the UN Charter Origins, Subsequent Developments in Law and Practice and (Mis)interpretation in the Context of Unilateral Secession Claims in the oscE Area
}

\author{
Tofig F. Musayev* \\ LL.M in International Human Rights Law, University of Essex, U.K., \\ Counsellor, Permanent Mission of Azerbaijan to the U.N. \\ tofigmusayev@hotmail.com \\ Rovshan Sadigbayli \\ M.A. in International Relations, Bilkent University, Turkey, Counsellor, \\ Permanent Mission of Azerbaijan to the O.s.C.E. \\ sadigbayli@gmail.com
}

\begin{abstract}
The article reviews the purposes and principles of the U.N. Charter in light of persistent claims voiced in the context of protracted conflicts in the OSCE area that the principle of self-determination allegedly grants the right to unilateral secession. The drafting history of the Charter indicate that States did not recognise a right to unilateral secession of a part of population of a State as a means of exercising self-determination. Subsequent development of this principle in law and in practice in the decades after the adoption of the Charter to a large extent has been shaped by the original ideas and understanding that went into the Charter. Invalidation at the international level of secessionist claims and actions, collective non-recognition of the resulting situations and abstention from aid or assistance that contributes to their consolidation are among legal and political consequences that have been applied and need to be consistently maintained with regard to the protracted conflicts in the OSCE area and their settlement processes.
\end{abstract}

* The opinions expressed in this article are those of the authors.

(C) TOFIG F. MUSAYEV AND ROVSHAN SADIGBAYLI, 2019 | DOI 10.1163/18750230-02801006 This is an open access article distributed under the terms of the prevailing CC-BY-NC license at the time of publication. 


\section{Keywords}

UN Charter - self-determination - territorial integrity - protracted conflicts

\section{Introduction}

The misconception of perceived contradiction between the principle of equal rights and self-determination of peoples and the principle of territorial integrity of States is deeply rooted in the academic community and the political domain alike. ${ }^{1}$ This dichotomy is nowhere more acute than in the context of the protracted conflicts in the OSCE area. ${ }^{2}$ The primary purpose of this article is not a detailed account of the historical background and political dynamics of these conflicts, which have been reviewed elsewhere. ${ }^{3}$ Rather, the focus of

1 See, for example, J. Summers, 'The Rhetoric and Practice of Self-Determination: A Right of All Peoples or Political Institutions?', in Nordic Journal of International Law, 2004, no. 73; J. Falkowski, 'Secessionary Self-Determination: A Jeffersonian Perspective', in Boston University International Law Journal, 1991, no. 209; Z. Velasco, 'Self-determination and Secession: Human Rights-based Conflict Resolution', in International Community Law Review, 2014, no. 16; E. Laing, 'The Norm of Self-Determination, 1941-1991', in California Western International Law Journal, 1992, no. 209; M. Gunter, 'Self-Determination or Territorial Integrity: The United Nations in Confusion' in World Affairs, 1979, no. 3, pp. 203-216; O. Kamanu, 'Secession and the Right of Self-Determination: An O.A.U. Dilemma' in The Journal of Modern African Studies, 1974, no. 3, pp. 355-376; M. Islam, 'Secessionist Self-Determination: Some Lessons from Katanga, Biafra and Bangladesh' in Journal of Peace Research, 1985, no. 3, pp. 211-221; L. Brilmayer, 'Secession and Self-Determination: A Territorial Interpretation', in Yale Journal of International law, 1991, no. 177; F. Kirgis, 'The Degrees of Self-Determination in the United Nations Era' in The American Journal of International Law, 1994, no. 2, pp. 304-310; Repertoire of Practice of the U.N. Security Council, Consideration of the provisions of Article 1, Paragraph 2 of the Charter, $1975^{-1980, ~ p p . ~ 407-408 . ~}$

2 The term 'protracted conflicts' is often used to describe the conflicts in Abkhazia and South Ossetia (Georgia), the conflict in and around the Nagorno-Karabakh region of Azerbaijan, the Transdniestrian conflict in Moldova and the crisis in and around Ukraine.

3 See, for example, V. Lozinskiy, 'The osce Mission in Nagorno-Karabakh', in Journal of International Peacekeeping, No. 1, 200o; A. Alexandru, 'The Role of Mediation in Settling Protracted Conflicts. Case Study: The Transnistrian Conflict', in Romanian Journal of International Law, No. 227, 2012; D. Lynch, 'Separatist States and Post-Soviet Conflicts', in International Affairs, 2002, No. 4; L. Laurinaviciute \& L. Bieksa, 'The relevance of remedial secession in the postSoviet "frozen conflicts", in International Comparative Jurisprudence, 2015, No. 66; Marie-Jose van Rie, "The Role of the OSCE in the Conflict in Georgia" in Security \& Human Rights, 2009, No. 318; T.D. Grant, 'Frozen Conflicts and International Law', in Cornell International Law Journal, No. 361, 2017. 
this research is on a common feature pertaining to all these conflicts - claims that the principle of self-determination allegedly grants the right to unilateral secession. Proponents of this view often try to find support to their legal position in the U.N. Charter and other international and regional documents. ${ }^{4}$ Given the implications of this theoretical discourse for the conflict settlement processes and its contribution to the intractability of these conflicts, it is worth briefly revisiting the Charter and other relevant documents to see whether such arguments really derive from them.

Recourse to the drafting history of the U.N. Charter, by following the general rules of the interpretation of the treaties, ${ }^{5}$ will be particularly valuable for our analysis. The Documents of the United Nations Conference on International Organization, ${ }^{6}$ which is considered by the United Nations as a complete documentary legislative history of the United Nations Conference, ${ }^{7}$ The Yearbook of

4 See, for example, on the conflicts in Georgia - Comment by the Information and Press Department on the $10^{\text {th }}$ anniversary of the August 2008 events in the Caucasus, Ministry of Foreign Affairs of the Russian Federation, No. 1462-07-08-2018, 7 August 2018, <http://www .mid.ru/ru/foreign_policy/news/-/asset_publisher/cKNonkJEo2Bw/content/id/3315007?p_p _id=101_INSTANCE_cKNonkJEo2Bw\&_101_INSTANCE_cKNonkJEo2Bw_languageId=en_GB $>$; On the crisis in and around Ukraine - Provisional Verbatim Record of $7138^{\text {th }}$ Meeting of the U.N.S.C., 15 March 2014, UN Doc. S/PV.7138, <https://www.securitycouncilreport.org/atf/ cf/\% $\%{ }_{7} 6{ }_{5} \mathrm{BFCF}_{9} \mathrm{~B}-6 \mathrm{D}_{27}-4 \mathrm{E}_{9} \mathrm{C}-8 \mathrm{CD}_{3}-\mathrm{CF}_{6} \mathrm{E}_{4} \mathrm{FFF}_{9} 6 \mathrm{FF} 9 \%$ d/s_pv_7138.pdf $>$; In the context of Armenia-Azerbaijan conflict, Note Verbale dated 21 March 2005 from the Permanent Mission of Armenia to the United Nations Office at Geneva addressed to the Office of the United Nations High Commissioner for Human Rights, Annex, 'Legal Aspects for the Rights to SelfDetermination in the Case of Nagorny Karabakh', U.N. Doc. E/CN.4/2005/G/23.

5 For the general rules of interpretation of the treaties, see articles $3^{1}$ and 32, Vienna Convention on the Law of Treaties, 8 ILM 679 (1969); B. Simma, D.-E. Khan, G. Nolte, A. Paulus, (ed.), The Charter of the United Nations. A Commentary, Oxford: Oxford University Press, 2012, 3 rd ed, vol. I, pp. $75^{-79}$.

6 Documents of the United Nations Conference on International Organization, San Francisco, (1945), vol. I-XXII, available at <http://digitallibrary.un.org/record/1300969?ln=en>.

7 The United Nations Conference on International Organization (referred to as U.N.C.I.o. or the Conference) convened in San Francisco, California, from 25 April-26 June 1945, for the purpose of drafting the Charter and the Statute of the International Court of Justice. The Conference had a complex organization and structure, divided into four Commissions tasked to recommend to the Conference action upon draft proposals submitted to it by the twelve drafting technical committees and sub-committees and four general committees. For the modalities of the Conference, see Doc. 25, DC/1, U.N.C.I.o. Documents, vol. v; Doc. 31, DC/6, April 27, U.N.C.I.O. Documents, vol. v, pp. 125-126. No stenographic transcript of proceedings of the Conference was kept except at the plenary sessions and public meetings of the Commissions. For all other meetings the Secretariat prepared a summary of the 
the United Nations $1946-1947,{ }^{8}$ reports of participating governments and academic research, provide useful insight into the negotiations of the Charter and its subsequent interpretation and will be consulted, where appropriate. ${ }^{9}$

The pages that follow will show that the development of the principle of self-determination in the decades after the adoption of the U.N. Charter to a large extent has been shaped by the original ideas and understanding that went into the Charter.

\section{The un Charter: Emergence of the Rules-based International Order}

While reviewing the Charter, one should follow the prescription of its drafters, who viewed the Purpose of the Charter as indivisible part with other provisions, namely Preamble and Principles, each of them being "equally valid, binding and operative". ${ }^{10}$ The rapporteur of the drafting Committee ${ }^{11}$ observed

discussions and of the decisions reached. Doc. 25, DC/1, U.N.C.I.O. Documents, vol. v, p. 19; Doc. 177, ST/5, vol. v, p. 200.

8 Yearbook of the United Nations 1946-1947, (1947). Department of Public Information, United Nations, Lake Success, New York, available at <http://www.unmultimedia.org/searchers/yearbook/page.jsp? volume $=1946-47 \&$ page $=1>$.

9 For the U.S. account of the drafting process, see "The Charter of the United Nations: Report to the President on the Results of the San Francisco Conference by the Chairman of the United States Delegation, the Secretary of State', June 26, 1945. Department of State publication No. 2349, Conference Series 71; V. Cassidy, R. Goodwin \& G. Dengler (eds.), (1967). Foreign Relations of the United States Diplomatic Papers [FRUs], 1945, General: The United Nations, vol. I, Washington: Government Printing Office, available at <http:// digital.library.wisc.edu/1711.dl/FRUS.FRUS1945vo1>; E. Perkins, S. Gleason, (eds.), (1966). Foreign Relations of the United States Diplomatic Papers, 1944, General, vol. I, Washington: Government Printing Office, available at <http://digital.library.wisc.edu/1711.dl/ FRUS.FRUS1944vo1>; For the Soviet Union records, seе История создания Организации Объединенных Наций. Разработка текста Устава оон (1944-1945) / Крылов С.Б.; под ред.: Тункина Г.И. - М.: Изд-во ИМО, 1960 [Krylov, S. (1949). Materials for the History of the United Nations: Volume I, "Framing of the Text of the Charter of the United Nations"], (In Russian).

10 Doc. 723, I/1/A/19, June 1, U.N.C.I.O. Documents, vol. vI, p. 699.

11 For the purpose of this article, particular attention will be paid to the work of Commission I, including its Committee 1 and drafting Sub-committee, established to draft Chapters I and II (Preamble, Purposes and Principles) of the Dumbarton Oaks Proposals to be submitted to the Conference for adoption as parts of the Charter. For organisational details, see Doc. 272, I/1/11, May 14, U.N.C.I.O. Documents, vol. VI, p. 286; Doc. 723, I/1/A/19, June 1, U.N.C.I.O. Documents, vol. vi, p. 696. 
that " $\mathrm{t}]$ he rights, duties, privileges, and obligations of the Organisation and of its members match with one another and complement one another to make a single whole. Each of them is construed to be understood and applied in function of the others". ${ }^{2}$ This latter point was specifically underlined in relation to the principle of self-determination, which, in view of the drafting Subcommittee, ${ }^{13}$ "as a provision of the Charter, should be considered in function of other provisions". ${ }^{4}$

This interdependence of the rights and obligations of States, which went eventually into article $2(2)$ of the Charter, ${ }^{15}$ warrants briefly touching upon the overall context in which the Charter was drafted and the key assumptions that guided the position of States. The deliberations during the informal meetings at Dumbarton Oaks (Washington, D.c.), where the Proposals for the Establishment of a General International Organisation ${ }^{16}$ were first drafted by the sponsoring Powers ${ }^{17}$ and the negotiations of the Charter at the San Francisco Conference, were centred around the post-war world order and the role of the new organization in the emerging new security architecture. The Dumbarton Oaks Proposals pronounced, inter alia, the principles of sovereign equality of States and refraining in international relations from the threat or use of force in any manner inconsistent with the purposes of the Organization - the principles that permeated the negotiations and which should be a starting point of any interpretation of Charter provisions. The overarching purpose of the Organisation was defined as maintaining international peace and security and to that end collective measures were envisaged for the prevention and removal of threats to the peace and suppression of acts of aggression or other breaches

12 Doc. 1006, I/6, June 16, U.N.C.I.o. Documents, vol. vi, p. 17.

13 The Sub-committee comprised of the Chairman (Ukrainian s.s.r.), Rapporteur (Syria), U.s., U.s.s.R., U.K., China, Belgium, Chile, France, New Zealand, Panama and the Union of South Africa.

14 Doc. 723, I/1/A/19, June 1, U.N.C.I.O. Documents, vol. VI, p. 704.

15 Doc. 944, I/1/34 (1), June 13, U.N.C.I.O. Documents, vol. vi, p. 457.

16 Yearbook of the United Nations 1946-1947, (1947). Department of Public Information, United Nations, Lake Success, New York, pp. 4, 9.

17 Informal discussions in Dumbarton Oaks on the general outline of the future International Organization was a result of the Moscow Declaration on General Security, adopted by the United States, the United Kingdom, the Soviet Union and China in October 1943. See Yearbook of the United Nations 1946-1947, (1947). Department of Public Information, United Nations, Lake Success, New York. The Four Powers were referred to as Sponsoring Powers or Governments because they sent out invitations to governments to attend the Conference in San Francisco. 
of peace and bringing about by peaceful means adjustment or settlement of international disputes. ${ }^{18}$

The question of whether the new world organisation should contain an explicit guarantee for the territorial integrity of States (modelled from Article $\mathrm{X}$ of the Covenant of the League of Nations) was specifically discussed at Dumbarton Oaks. The U.K. recognised the importance of the principle of territorial integrity, which, in its view, should be part of the obligations of member States towards each other, rather than guarantees of the organisation. ${ }^{19}$ It argued that "...many States will be more interested in the establishment of some concrete security system ready for immediate action than in guarantees of frontiers which in themselves do little to prevent the invasion and occupation of territory by the armed forces of another State". ${ }^{20}$

China suggested the inclusion in the Proposals of a detailed list of general principles to guide the organisation in settlement of disputes, ${ }^{21}$ and, specifically, that "[all] member states shall respect and maintain the territorial integrity and political independence of each other against external aggression". 22 The Chinese proposal also contained a provision stipulating that "a member state shall not give any support or assistance, or accord any de facto or de jure recognition, to any situation that is created by force in contradiction to the principles of the Charter". ${ }^{23}$ During the discussions, the Chinese delegation argued that adding some assurances in regards to the maintenance of the political independence and territorial integrity of member States would promote

18 Doc. 1, G.1, U.N.C.I.o. Documents, vol. III. See also, Memorandum by the Under Secretary of State (Stettinius) to the Secretary of State, August 29, 1944, in U.s. State Dept., FRUS, 1944, vol. pp. 746-747, Document 430.

19 R. Russell, A History of the United Nations Charter: The Role of the United States 1940-1945. Washington, D.C.: Brookings Institution, 1958, p. $45^{6}$.

20 See Section III, 'The Question of Guarantees' in Memorandum B: The Pacific Settlement of Disputes, the Question of Guarantees and the Conditions in Which Action Should be Taken for the Maintenance of Peace and Security, Tentative Proposals by the United Kingdom for a General International Organization, July 22, 1944, in U.s. State Dept., FRUS, 1944, vol. 1, pp. 680, 685, Document 404.

21 R. Russell, A History of the United Nations Charter: The Role of the United States 1940-1945. Washington, D.C.: Brookings Institution, 1958, p. 457.

22 Tentative Chinese Proposals for a General International Organization, August 23, 1944, in U.s. State Dept., FRUS, 1944, vol. 1, p. 719, Document 422.

23 Section XVI, Pacific Settlement of International Disputes, Tentative Chinese Proposals for a General International Organization, August 23, 1944, in U.s. State Dept., FRUS, 1944, vol. 1, p. 725, Document 422. (Emphasis original). 
confidence in the Organization on the part of smaller States. ${ }^{24}$ The U.s. and the U.K. maintained that these principles were clearly inherent in the principle of sovereign equality of States. China concurred with this understanding. ${ }^{25}$

The discussions at the United Nations Conference reveal that the participants were ready to attribute greater responsibility to an international organisation to maintain international peace and security in exchange for the assurances of the juridical equality of all States and explicit guarantees in the new Charter of certain agreed rules of international conduct to be observed by all. ${ }^{26}$ Many delegations advocated for making explicit in the Declaration of Purposes some provision for an effective system of guarantees of the territorial integrity and "freedom from aggression" of all States members of the International Organisation. ${ }^{27}$ Proposals to include in the Charter guarantees for the territorial integrity featured in the amendments submitted to the Committee for consideration by almost one third of the delegations present at the Conference. $^{28}$

24 Informal Minutes of Meeting No. 2 of the Joint Steering Committee, October 2, 1944, in U.s. State Dept., Frus, 1944, vol.., p. 859, Document 490; Memorandum by the Under Secretary of State (Stettinius) to the Secretary of State on the Second Plenary Session of Conversations With the Chinese, October 3, 1944, in U.s. State Dept., FRUs, 1944, vol. 1, p. 864, Document 493.

25 Memorandum by the Under Secretary of State (Stettinius) to the Secretary of State on Meeting of the Joint Formulation Group, October 4, 1944, in U.s. State Dept., FRUS, 1944, vol. 1, p. 866, Document 494.

26 Doc. 2, G/7 (g), May 2, U.N.C.I.o. Documents, vol III, pp. 26o-261 (Panama); Doc. 2, G/7 (i) (1), May 6, U.N.C.I.o. Documents, vol III, pp. 292-293 (Chile); U.N.C.I.o. Documents, vol III, pp. 308-314 (Netherlands); Doc. 2, G/7 (o), March 21, U.N.C.I.o. Documents, vol III, pp. 376-377 (France); Doc. 2, G/7 (p), May 1, U.N.C.I.o. Documents, vol. III, pp. 398-399, 404 (Ecuador).

27 Doc. 272, I/1/ 11, May 14, U.N.C.I.O. Documents, vol. vI, p. 286; Doc. 22, P/7, April 29, U.N.C.I.o. Documents, vol. I, p. 232 (Czechoslovakia); Doc. 22, P/7, April 29, U.N.C.I.o. Documents, vol. I, p. 232 (Iran); Doc. 24, P/8, April 29, U.N.C.I.o. Documents, vol. I, p. 299 (Uruguay); Doc. 58, P/15, May 2, U.N.C.I.o. Documents, vol. I, p. 509 (New Zealand); Doc. 58, P/15, May 2, U.N.C.I.o. Documents, vol. I, p. 517 (Venezuela); Doc. 2o, P/6, April 28, U.N.C.I.o. Documents, vol. I, pp. 173-174 (Australia).

28 Doc. 382, I/1/ 19, May 17, U.N.C.I.o. Documents, vol. vi, p. 303; Doc. 215, I/1/ 10, May 11, vol. VI, p. 525; Doc. 2, G/7 (a) (1), May 5, U.N.C.I.o. Documents, vol. III, p. 35 (Uruguay); Doc. 382, I/1/19, May 17, U.N.C.I.O. VI, p. 304 (Peru); Doc. 2, G/7 (c), April 23, U.N.C.I.o. Documents, vol. III, p. 65; Doc. 2, G/7 (c), May 5, U.N.C.I.o. Documents, vol. III, p. 179 (Mexico); Doc. 2, G/7 (p), May 1, U.N.C.I.o. Documents, vol. III, p. 399 (Ecuador); Doc. 2, G/7 (m), U.N.C.I.o. Documents, vol. III, p. 349 (Honduras); Doc. 2, G/7 (e), May 2, U.N.C.I.o. Documents, vol. III, p. 233; Doc. 2, G/7 (e) (2), May 4, vol. III, p. 246 (Brazil); Doc. 2, G/7 (q) (1), May 5, U.N.C.I.o. Documents, vol. III, p. 454 (Egypt); Doc. 2, G/14 (b), May 1, U.N.C.I.o. 
The Delegations advocated for maintaining peace at all costs, but not at the cost of justice. Many delegations insisted on inclusion among the purposes of the Organisation of the reference to justice and international law, which, in their view, is a prerequisite for international peace and security. ${ }^{29}$ After prolonged discussions, it was agreed that one of the purposes of the Charter would be to bring about adjustment or settlement of international disputes or situations which may lead to a breach of the peace in conformity with the principles of justice and international law. ${ }^{30}$ No definition of the term "justice" was provided. However, the discussions in San Francisco indicate that the delegations wanted to prevent injustices in international relations that emerged from the past wars, including acts of aggression and "Munich agreement"-type deals, resulting in annexation of territories of sovereign States. ${ }^{31}$ If one takes into consideration that most of the wars fought throughout the past centuries were in some way or another about territory and resulted in territorial conquest and

Documents, vol. III, p. 467 (Czechoslovakia); Doc. 2, G/14 (f), May 2, U.N.C.I.o. Documents, vol. III, p. 486 (New Zealand); Doc. 2, G/14 (g), U.N.C.I.o. Documents, vol. III, p. 497 (Cuba); Doc. 2, G/14 (m), May 5, U.N.C.I.o. Documents, vol. III, p. 554 (Iran); Doc. 2, G/14 (n), May 5, Uncio Documents, vol. III, p. $55^{8}$ (Ethiopia); Doc. 2, G/14 (s), May 6, U.N.C.I.o. Documents, vol. III, pp. 587-588 (Colombia); Doc. 2, G/14 (r), May 5, U.N.C.I.o. Documents, vol. III, pp. $5^{82-583}$ (Bolivia).

29 See, for example, Doc. 2, G/7 (p), May 1, U.N.C.I.o. Documents, vol. III, p. 398 (Ecuador); Doc. 2, G/7 (q), May 1, U.N.C.I.o. Documents, vol III, pp. 447, 453, (Egypt); Doc. 2, G/14 (n), May 1, U.N.C.I.o. Documents, vol III, p. 558, (Ethiopia); Doc. 2, G/7 (F), April 23, U.N.C.I.o. Documents, vol. III, p. 256, (Guatemala); Doc. 2, G/7 (j) 1, May 1, U.N.C.I.o. Documents, vol. III, p. 323, (Netherlands); Doc. 2, G/14 (m), May 5, U.N.C.I.o. Documents, Vol III, p. 554, (Iran); Doc. 2, G/7 (c) (1), May 5, U.N.C.I.o. Documents, vol. III, p. 178, (Mexico); Doc. 2, G/29, May 5, U.N.C.I.O. Documents, vol. III, p. 622, (U.s., U.K., U.s.s.R. and China); Doc. 2, G/14 (e), May 1, U.N.C.I.o. Documents, vol. III, p. 481, (Turkey); Doc. 995, I/1/41, June 15, U.N.C.I.O. Documents, vol. vi, p. 628 (Uruguay).

30 Doc. 1006, I/6, June 15, U.N.C.I.O. Documents, vol. vi, pp. 21-34. On discussion of this topic, see Doc. 1, G/1, May 1, U.N.C.I.o. Documents, vol. III, p. 25; Tentative Chinese Proposals for a General International Organization, August 23, 1944, in U.s. State Dept., FRUS, 1944, vol. 1, p. 718, Document 422; Memorandum by the Under Secretary of State (Stettinius) to the Secretary of State on Meeting of the Joint Formulation Group, October 4, 1944, in U.s. State Dept., FRUS, 1944, vol. 1, pp. 865-866, Document 494; Informal Minutes of Meeting No. 3 of the Joint Steering Committee, October 4, 1944, in U.s. State Dept., FRUS, 1944, vol. 1, p. 869, Document 495 .

31 Doc. 2, G/7 (j), U.N.C.I.o. Documents, vol. III, p. 312 (Netherlands); Doc. 272, I/1/11, May 14, U.N.c.I.o. Documents, vol. vi, p. 286; История создания Организации Объединенных Наций. Разработка текста Устава оон (1944-1945) / Крылов С.Б.; под ред.: Тункина Г.И. - М.: Изд-во ИМО, 1960, р. 113. 
arbitrary change of frontiers, ${ }^{32}$ the intention of the States becomes obvious. Requests by delegations to include in the Charter explicit provisions relating not only to respect for justice, but also for an effective system of mutual insurance or guaranty of the territorial integrity of States, supports this view. ${ }^{33}$

\section{San Francisco Dilemma: Reconciling Respect for Territorial Integrity and Non-recognition of Territorial Conquest}

Committee 1 had to respond to the requests from the many delegations to have explicit language on protection of territorial integrity and agreed that the relevant articles of the Charter, related to the principles, should be re-worded to include the ideas that States are juridically equal; that they enjoy the rights inherent in sovereignty and that "any change in the status quo resulting from violence, force or undue pressure should not be recognized by the other members and should be considered incompatible with membership in the Organization". ${ }^{34}$

On the other hand, the Committee had to take into account the views of the four sponsoring Powers, which, albeit for opposing reasons, were reluctant to include a positive obligation to guarantee the territorial integrity and political independence of States. ${ }^{35}$ As World War II neared its end, the question of boundaries in Europe was a point of contention among the major Allied Powers. Such a commitment was perceived to imply guaranteeing "territorial status-quo", 36

32 See, for example, J. Vasquez, 'Why Do Neighbors Fight? Proximity, Interaction, or Territoriality', in Journal of Peace Research, no. 3, 1995, pp. 277-293; D. Johnson, \& M. Toft, 'Grounds for War: The Evolution of Territorial Conflict, International Security', in International Security, no. 3, 2014, pp. 7-38.

33 Doc. 272, I/1/ 11, May 14, U.N.C.I.o. Documents, vol. vI, p. 286.

34 Doc. 423, I/1/20, U.N.C.I.o. Documents, May 19, vol. VI, p. 311-312; Doc. 337, I/1/A/2, Annex 1, May 16, U.N.C.I.o. Documents, vol. vi, p. 647; Doc. 337, I/1/A/2, Annex 3, May 16, vol. vi, p. 649 .

35 M. Davis, 'The United Nations Charter: Development and Text, First Commission: General Provisions', in M. Davis, H. Gilchrist, G. Kirk, N. Padelford, 'The United Nations Charter with Explanatory Notes of its Development at San Francisco', in International Conciliation, 1945, no. 413, Sec. 1, p. 445; R. Russell, $A$ History of the United Nations Charter: The Role of the United States 1940-1945, Washington, D.C.: Brookings Institution, 1958, pp. 672-675.

36 История создания Организации Объединенных Наций. Разработка текста Устава оон (1944-1945) / Крылов С.Б.; под ред.: Тункина Г.И. - М.: Изд-во ИМО, 196о, р. 113; Minutes of the Thirty-Ninth Meeting of the United States Delegation, Held at San Francisco, May 15, 1945, in U.s. State Dept., F RUS, 1945, vol. 1, p. 748, Document 228, vol. 1, p. 726 ; See also Minutes of the Fortieth Meeting of the United States Delegation, May 15, 1945, in U.S. State Dept., FRUS, 1945, vol. 1, p. 748, Document 231. 
to which they were not ready to subscribe due to pending decisions on boundaries in post-War Europe, that were finalized only in February 1947.37

This dilemma is clearly visible in the discussions within the U.S. Delegation. The U.s. was not per se against respect for territorial integrity, which it considered was embedded in the sovereign equality principle, but could not accept the wording on "guarantees" that, in its view, would result in "freezing of Russian boundaries achieved by conquest". 38 The U.s. position was largely shaped by the policy of non-recognition of the Soviet incorporation of the Baltic States, ${ }^{39}$ - the policy rooted in the Stimson doctrine of non-recognition of territorial acquisition by conquest. ${ }^{40}$ At the same time, the U.s. did not want to give an impression that it favoured the change of boundaries. ${ }^{41}$ Nor could it afford ignoring "strong feeling among many nations at San Francisco that the Charter should include a statement emphasizing respect for the territorial integrity" ${ }^{42}$

The territorial integrity clause eventually found its place among the principles in Article 2 of Chapter II, as was proposed by Australia, ${ }^{43}$ which codifies

37 J. Campbell, 'The European Territorial Settlement', in Foreign Affairs, 1947, no. 1, pp. 196-218; R. Russell, A History of the United Nations Charter: The Role of the United States 1940-1945, Washington, D.C.: Brookings Institution, 1958, pp. 44-45, 157-159.

38 Minutes of the Thirty-Ninth Meeting of the United States Delegation, May 15, 1945, in U.S. State Dept., FRUS, 1945, vol. 1 p. 748, Document 228. See also Minutes of the Fortieth Meeting of the United States Delegation, May 15, 1945, in U.s. State Dept., FRUS, 1945, vol. 1 p. 748, Document 231.

39 See a Statement by acting Secretary of State Sumner Welles of 23 July 1940, known as 'Welles Declaration', which condemned the 1940 'annihilation' of the political independence and territorial integrity of the Baltic States by the Soviet Union and established the United States policy of refusing to recognize the new Soviet governments of Estonia, Latvia, and Lithuania, available at <http://digitalarchive.wilsoncenter.org/document/144967>; R. Russell, A History of the United Nations Charter: The Role of the United States 1940-1945, Washington, D.C.: Brookings Institution, 1958, p. 33.

40 R. Current, 'The Stimson Doctrine and the Hoover Doctrine', in The American Historical Review, 1954, no. 3, pp. 513-542.

41 Minutes of the Thirty-Ninth Meeting of the United States Delegation, May 15, 1945, in U.s. State Dept., FrUS, 1945, vol. 1, p. 375, Document 173.

42 Charter of the United Nations: Report to the President on the results of San Francisco Conference by the Chairman of the United States Delegation, the Secretary of State, June 26, 1945, Department of State publication 2349, Conference Series 71, Washington: U.s. Govt. Print. Off., pp. 39-40, 41.

43 Doc. 2, G/14 (1), May 5, U.N.C.I.o. Documents, vol. III, p. 543; Doc. 655, I/1/A /15, May 28, vol. vI, p. 684; Doc. 656, I/1/A/16, May 28, vol. vI, p. 687; Doc. 723, I/1/A/19, June 1, U.N.C.I.O. Documents, vol. VI, p. 702. 
that the territorial integrity of States is protected by the legal prohibition on the threat or use of force. ${ }^{44}$

The discussions around this article were also related to the proposal of New Zealand to include the commitment of collective action to resist every act of aggression against any member. This proposal had substantial majority in its favour during the vote in the Committee, short of required two-thirds majority ${ }^{45}$ and was opposed by the delegations of the U.s., U.K. and China. ${ }^{46}$ The United States and the U.K. contended that the term "aggression" was too narrow in comparison with explicit word "force", and would give opportunity to a State to engage in an act of aggression while calling it by another name. ${ }^{47} \mathrm{In}$ view of the United States, many kinds of aggression would be covered in the Charter by the words "threat to the peace". 48

The discussions around the principle of territorial integrity also arose in connection with the principle of sovereign equality - the first principle of the Charter. This principle, which was rightly described as the "essential character" of the United Nations, ${ }^{49}$ is often overlooked in the scholarly research on this subject. A number of delegations in San Francisco expressed desire to clarify this principle to specify more precisely attributes of the sovereignty of States

44 Doc. 810, I/1/30, June 6, U.N.C.I.o. Documents, vol. vI, p. 342; Doc. 739, I/1/A/19 (a), June 1, U.N.C.I.O. Documents, vol. VI, pp. 720-721; Doc. 1123, I/8, June 20, U.N.C.I.O. Documents, vol. vI, pp. 69, 82; Doc. 1187, I/13, June 24, U.N.C.I.O. Documents, vol. VI, p. 204; Doc. 1142, I/9, June 21, U.N.C.I.O. Documents, vol. vI, p. 230; Doc. 784, I/1/27, June 5, U.N.C.I.o. Documents, vol. vI, p. 334; Doc. 885, I/1/34, June 9, U.N.C.I.o. Documents, vol. vI, p. 400 and Appendix I/1/34 (a); Doc. 784, I/1/27, June 5, U.N.C.I.o. Documents, vol. vI, p. 335; Doc. 908, I/1/34 (a), June 11, U.N.C.I.O. Documents, vol. vI, p. 404.

The rules of procedure regarding the adoption of the provisions of the Charter required a stringent two-thirds majority of votes of the delegations present and voting in public sessions and meetings. A proposal, which received a majority vote short of the required twothirds in a Committee meeting, should have been reconsidered in a Commission meeting or in the plenary session of the Conference. See Doc. 25, DC/1, U.N.C.I.O. Documents, vol. v, p. 16 ; Doc. 165, ST/4, May 9, vol. v, p. 188; Doc. 177, ST/5, vol. v; Doc. 95, I/1/2, May 5, vol. vi, p. 269; M. Davis, H. Gilchrist, G. Kirk, N. Padelford, 'The United Nations Charter with Explanatory Notes of its Development at San Francisco', in International Conciliation, 1945, no. 413, Sec. 1, p. 442.

46 Doc. 810, I/1/30, June 6, U.N.C.I.o. Documents, vol. vI, pp. 342-346; Doc. 1179, I/9 (1), June 24, U.N.C.I.O. Documents, vol. vI, p. 247 .

47 Doc. 810, I/1/30, June 6, U.N.C.I.o. Documents, vol. vI, p. 344, (U.S.A.); Doc. 866, I/1/30 (a), June 8, vol. vi, p. 356, (U.K.).

48 Doc. 810, I/1/30, June 6, U.N.C.I.o. Documents, vol. vi, p. 344.

49 L. Goodrich, 'From League of Nations to United Nations', in International Organization, 1947 , no. 1, p. 8 . 
such as political independence, juridical equality, and territorial integrity..$^{50}$ It was eventually agreed that the term "sovereign equality" would be maintained as originally drafted with the explanation of its meaning in the report accompanying it, stipulating that it includes also the requirement to respect the territorial integrity of States. ${ }^{51}$ The sovereign equality principle was thus viewed by the Conference as reinforcing the principle of territorial integrity. ${ }^{52}$

To sum up, respect for the territorial integrity of States and inviolability of their frontiers was clearly one of the central questions for many delegations, and in the final reading of the Charter was understood as being protected explicitly under the legal prohibition of the use of force against territorial integrity and implicitly under the principles of sovereign equality and settlement of international disputes in conformity with the principles of justice and international law. States interpreted prohibition of the use of force in broader terms and included not only overt aggression and unlawful military actions, but all other indirect measures of force, which were also qualified as breach of the peace and were regarded as being of the same gravity as aggression. The political and legal significance of codification of prohibition of the use of force against territorial integrity was the duty of non-recognition for third parties of situations achieved through unlawful threat or use of force, which has direct implications on how States interpreted application of the self-determination principle, including in situations of protracted conflicts.

$50 \quad$ Doc. 2, G/7 (b) (1), U.N.C.I.o. Documents, vol. III, p. 52, (Haiti); Doc. 2, G/14 (o), May 6, U.N.C.I.o. Documents, vol. III, p. 564 (Dominican Republic); Doc. 2, G/7 (F), April 23, U.N.C.I.o. Documents, vol. III, p. 256, (Panama), Doc. 2, G/7 (g), May 2, vol. III, p. 260, (Chile); Doc. 2, G/7(1), May 2, vol. III, p. 283 and Doc. 2, G/7 (i) (1), May 6, vol. III, p. 293; Doc. 1123, I/8, June 20, U.N.C.I.o. Documents, vol. vi, p. 66; See also Doc. 2, G/14 (u), May 6 , vol. III, p. 596, (Peru).

51 Doc. 1123, I/8, June 20, U.N.C.I.O. Documents, vol. vI, p. 69. On approval of this paragraph by Committee 1 see Doc. 784, I/1/27, June 5, U.N.C.I.o. Documents, vol. vI, p. 331; Doc. 1142, I/9, June 21, U.N.C.I.o. Documents, vol. VI, p. 230. See also report by the Drafting Subcommittee Doc. 739, I/1/A/19 (a), 1 June, vol. vI, p. 717-718; Doc. 944, I/1/34 (1), June 13, U.N.C.I.O. Documents, vol. vi, p. 457.

52 Doc. 1123, I/8, June 20, U.N.C.I.o. Documents, vol. VI, p. 68 (Peru); Doc. 1142, I/9, June 21, U.N.C.I.O. Documents, vol. vi, p. 23o; Charter of the United Nations: Report to the President on the results of San Francisco Conference by the Chairman of the United States Delegation, the Secretary of State, June 26, 1945, Department of State publication 2349, Conference Series 71, Washington: U.s. Govt. Print. Off., pp. 39-40. 


\section{The Scope of Self-determination in Light of the Context and Purpose of the U.N. Charter}

Reference to equal rights and self-determination of peoples was absent from the original Dumbarton Oaks Proposals and was proposed at a later stage by the Soviet Union at the San Francisco Conference. No details were provided on its meaning at that time..$^{53}$ It was submitted for inclusion in Chapters I (Purposes) and IX (Arrangements for economic and social cooperation) on behalf of the Four as a joint proposal to the original draft. ${ }^{54}$ This unanimity of the sponsoring governments, however, seemed to be a matter of tactics in negotiations. The U.s. delegation did not want to come out as opposed to such a provision, but questioned internally the reasons behind this proposal, fearing that "it could be used to cover the expansion of the Soviet Union".55

The outcome of the negotiations within the drafting Sub-committee was the agreement on the text of Chapter I (Purposes), containing the proposal on self-determination with a reservation that "further agreement as to where in this Chapter the New Zealand amendment with regard to the territorial integrity should be inserted". ${ }^{56}$ It appears that the members of the Sub-committee agreed to the proposal on self-determination on condition that the respect for territorial integrity would also be inserted into the Charter. This explicit linkage is crucial for any analysis of the scope of the Charter provisions on self-determination.

The reports of the closed meetings of the Committee provide only summaries of the discussions held around this principle. ${ }^{57}$ However, even those records that are available indicate that there was a strong opposition to the idea that self-determination could imply the right of secession. It should be also noted that the discussion around this question was a theoretical one, since no delegation interpreted this principle as granting such a right.

53 Minutes of the First Four-Power Consultative Meeting on Charter Proposals, May 2, 1945, in U.S. State Dept., FRUS, 1945, vol. 1, p. 551, Document 201.

54 Doc. 2, G/29, May 5, U.N.C.I.O. Documents, vol. III, p. 622; Doc. 165, ST/4, May 9, vol. v, p. 189; Doc. 924, II/12, June 12, U.N.C.I.O. Documents, vol. virI, p. 80; Minutes of the First Four-Power Consultative Meeting on Charter Proposals, Held at San Francisco, May 2, 1945, in U.s. State Dept., FRUS, 1945, vol. 1, p. 551, Document 201.

Minutes of the Twenty-Sixth Meeting of the United States Delegation, Held at San Francisco, Wednesday, May 2, 1945, in U.s. State Dept., FRUS, 1945, vol. 1, p. 546, Document 200.

56 Doc. $384, \mathrm{I} / 1 / \mathrm{A} / 5$ (1), May 18, U.N.C.I.o. Documents, vol. vi, p. 660.

57 Doc. 308, I/1/14, May 15, U.N.C.I.o. Documents, vol. vi, p. 291; R. Russell, $A$ History of the United Nations Charter: The Role of the United States 1940-1945, Washington, D.C.: Brookings Institution, 1958, p. 811. 
The discussions in San Francisco primarily revolved around references to "peoples" and "nations" in the paragraph dealing with self-determination. The delegates of Belgium, France, Canada and Chile objected to juxtaposition between the two terms, arguing that this could imply the right to secession. ${ }^{58}$ The Coordination Committee ${ }^{59}$ attempted to clarify the meaning of the term "peoples" as "groups of human beings who may, or may not, comprise states or nations", whereas the term "nations", in its view, was used in the sense of all political entities such as States, colonies, mandates, and protectorates. ${ }^{60}$ Based on this understanding, the Coordination Committee saw no difficulty in juxtaposition of terms "peoples" and "nations". ${ }^{61}$

With regard to Belgium's proposal to include into this paragraph a reference to "respect for the essential rights and equality of states", along with the peoples' right of self-determination, the Sub-committee explained that the intention of Article 1 was "to proclaim the equal rights of peoples as such, consequently their right to self-determination". The Sub-committee made an important clarification that "[e]quality of rights, therefore, extends in the Charter to states, nations, and peoples". ${ }^{62}$ Two conclusions can be drawn from these discussions: that the right to self-determination of peoples (who may or may not comprise States or nations) cannot undermine or otherwise limit the rights of other peoples comprising nations and States; and that it does not follow from the interpretation of the term "peoples" by the Committee that it was understood as necessarily applying to a part of the population of an existing State. ${ }^{63}$

The report of the sixth meeting of Committee 1, summarizing the discussions around self-determination, contains the following record of what is

58 Doc. 374, I/1/17, 17 May, U.N.C.I.o. Documents, vol. VI, p. 300 (Belgium); Doc. WD 410, CO/170, June 20, U.N.C.I.o. Documents, vol. XVII, p. 142 (France, Canada, Chile); Doc. WD 381, Co/156, June 18, U.N.C.I.O. Documents, vol. XVIII, p. 658.

59 In accordance with the Conference procedures, the Coordination Committee was responsible for reviewing Charter language received from the Committees with a view to eliminating possible inconsistencies between them and preparing the final draft of the Charter. Doc. 243, ST/8, May 11, U.N.C.I.o. Documents, vol. v, p. 222.

60 Doc. WD 381, Co/156, June 18, U.N.C.I.o. Documents, vol. XVIII, pp. 657-658.

61 Doc. WD 381, Co/156, June 18, U.N.C.I.o. Documents, vol. XVIII, p. 658.

62 Doc. 723, I/1/A/19, June 1, U.N.C.I.o. Documents, vol. vI, p. 704.

63 For discussion on these terms, see H. Quane, 'The United Nations and the Evolving Right to Self-Determination', in The International and Comparative Law Quarterly, 1998, no. 3, pp. $542-546$. 
understood by some scholars ${ }^{64}$ as consensus reached at the San Francisco Conference on the scope of the principle:

[c] oncerning the principle of self-determination, it was strongly emphasized on the one side that this principle corresponded closely to the will and desires of peoples everywhere and should be clearly enunciated in the Charter; on the other side, it was stated that the principle confirmed to the purposes of the Charter only insofar as it implied the right of selfgovernment of peoples and not the right of unilateral secession. ${ }^{65}$

In the final report submitted to Commission I, the Committee clarified that:

the principle of equal rights of peoples and that of self-determination are two complimentary parts of one standard of conduct; that the respect of that principle is a basis for the development of friendly relations and is one of the measures to strengthen universal peace; and that an essential element of the principle in question is a free and genuine expression of the will of the people, which avoids cases of alleged expression of the popular will, such as those used for their own ends by Germany and Italy in later years. ${ }^{66}$

Reference to Germany and Italy in this context is particularly noteworthy and apparently was intended to underscore that self-determination is incompatible with occupation and territorial conquest under the disguise of plebiscite, similar to the one staged by Nazi Germany in Austria in April $1938,{ }^{67}$ or to the South Tyrol Option Agreement of 1939, which resulted in dislocation of the

64 M. Zubeida, 'The Principle of Self-Determination in International Law', in International Law, 1971, no. 479, p. 483.

65 Doc. 343, I/1/16, May 16, U.N.C.I.o. Documents, vol. vi, p. 296.

66 Doc. 885, I/1/34, June 9, U.N.C.I.o. Documents, vol. vI, p. 396; Doc. 944 , I/1/34 (1), June 13, vol. vi, p. 455 .

67 A. Hitler allegedly secured 'popular support' in a referendum on the reunion (Anschluss) with Germany, held in Austria, which Germany had already occupied a month earlier. For more on this, see 'Communication from the German Government Concerning the Situation in Austria in Relation to the League of Nations', 18 March 1938, available at U.N. Office at Geneva Archives, <http://biblio-archive.unog.ch/Dateien/CouncilMSD/C-102M-54-1938-VII_EN.pdf>; See also H. Wright, 'The Legality of the Annexation of Austria by Germany', in American Journal of International Law, 1944, no. 4, pp. 621-635. 
population from the South Tyrol region, resembling the notorious practice of ethnic cleansing. ${ }^{68}$

The final approved reports of the Commissions were regarded by the drafters as the authoritative interpretation of the text of the Charter. ${ }^{69}$ Positions and proposals receiving wide support during the discussions were recorded in the reports of the Committees that were endorsed by the Commissions. Which amendments and ideas of the delegations would be reflected or omitted in the final reports was carefully decided upon by the Chairs and Rapporteurs of the Committees. ${ }^{70}$ It seems that the view that self-determination does not imply the right to secession was recorded in the report of the full Committee deliberately to underscore this understanding.

The discussions held in Committee II/4, dealing with the trusteeship system for the supervision of the trust territories and dependent peoples, ${ }^{71}$ as well as the views expressed by the delegations of the Soviet Union and other sponsoring governments on the objective of trusteeship, give indication that populations of non-self-governing territories and dependent peoples were regarded as primary beneficiaries of self-determination. ${ }^{72}$ One should also be mindful

68 C. Latour, 'Germany, Italy and South Tyrol, 1938-45', in The Historical Journal, 1965, no. 1, pp. 95-111.

69 See Statement of the President of the Commission I on this point. Doc. 1187, I/13, June 24, U.N.C.I.o. Documents, vol. vI, p. 202; See also the Report of the drafting subcommittee, Doc. 723, I/1/A/5/19, June 01, U.N.C.I.O. Documents, vol. vI, p. 701. Doc. 926, I/1/36, June 12, U.N.C.I.O. Documents, vol. vI, pp. 422, 423.

71 Doc. 404, II/4/17, May 18, U.N.C.I.O. Documents, vol. X, pp. 451-453; Doc. 712, II/4/30, May 31, vol. X, p. 497 .

72 Doc. 310, II/4/11, May 15, U.N.C.I.o. Documents, vol. X, p. 440, 441; Doc. 1144, II/16, June 21, U.N.C.I.o. Documents, vol. viII, p. 153; Doc. 2, G/7 (c), April 23, U.N.C.I.o. Documents, vol. III, p. 146 (Mexico); Doc. 2, G/26 (f), May 11, U.N.C.I.o. Documents, vol. III, p. 618 (USSR); For the U.s. view, see Minutes of the Forty-Fifth Meeting of the United States Delegation, May 18, 1945, in U.s. State Dept., FRUS, 1945, vol. 1, p. 794, Document 239; See also F. Kirgis, 'Degrees of Self-Determination in the United Nations Era', in American Journal of International Law, 1994, no. 2, p. 304; История создания Организации Объединенных Наций. Разработка текста Устава оон (1944-1945) / Крылов С.Б.; под ред.: Тункина Г.И. - М.: Изд-во ИМО, 196o, pp. 111-112; R. Russell, A History of the United Nations Charter: The Role of the United States 1940-1945, Washington, D.C.: Brookings Institution, 1958, pp. 75-91; 'Заявление товарища В.М. Молотова на пресс-конференции в Сан-Франциско' [Statement by comrade V.M. Molotov at the press-conference in SanFrancisco], Известия, 9 Мая 1945 г., № 107 (8717), (In Russian), available at <https://www. oldgazette.ru/izvestie/og051945/indexi.html>, (Emphasis added); See also, R. Russell, $A$ History of the United Nations Charter: The Role of the United States 1940-1945, Washington, D.C.: Brookings Institution, 1958, p. 811. 
of the distinction between the meaning presently conferred to the term "secession" as attempted non-consensual separation of a part of a territory of a sovereign State and the granting of independence to colonial peoples, which was subject of lengthy debates in San Francisco and which was interchangeably referred to as secession, but always in the context of the decolonisation process. ${ }^{73}$

Discussion of the scope of the equal rights and self-determination principle in the Charter will be incomplete without mentioning the last, seventh principle pertaining to the domestic jurisdiction of States. The drafting history of the Charter indicates that a distinction was made between the international disputes and situations, which might lead to a breach of the peace and thus warrant attention of the United Nations and matters belonging to the realm of domestic jurisdiction of States. ${ }^{74}$ That the self-determination principle does not imply the right of secession of a part of population of a State, some argue, follows clearly from principle 2(7), which leaves to the States to handle questions that fall within their domestic jurisdiction. ${ }^{75}$ On this point, Koskenniemi, citing the legal opinion on the Aaland Islands, ${ }^{76}$ argues that " $[\mathrm{w}]$ hether or not a people within the boundaries of a State 'definitivement constitué' may enjoy

73 H. Quane, 'The United Nations and the Evolving Right to Self-Determination', in The International and Comparative Law Quarterly, 1998, no. 3, p. 547; V. Van Dyke, 'Self-Determination and Minority Rights', in International Studies Quarterly, 1969, no. 3, pp. 231-233; See also remarks of Chile on this subject, Doc. WD 410, CO/170, June 20, U.N.C.I.O. Documents, vol. XVII, p. 142.

74 Doc. 1, G/1, U.N.C.I.o. Documents, vol. III, p. 14; See also R. Russell, $A$ History of the United Nations Charter: The Role of the United States 1940-1945. Washington, D.C.: Brookings Institution, 1958, pp. 463-464; L. Goodrich, E. Hambro (eds.), Charter of the United Nations: Commentary and Documents, Boston: World Peace Foundation, 1946, p. 72; The U.s. Secretary of State in his final report on the Charter underscored this understanding by saying that "...on the initiative of the Sponsoring Powers, the word 'international' was added to make it perfectly clear that the Organisation would concern itself only with disputes among the nations, a conclusion stated more explicitly in the seventh principle." Charter of the United Nations: Report to the President on the results of San Francisco Conference by the Chairman of the United States Delegation, the Secretary of State, June 26, 1945, Department of State publication 2349, Conference Series 71, Washington: U.s. Govt. Print. Off., p. 40 (Emphasis original).

75 L. Goodrich, L., E. Hambro (eds.), Charter of the United Nations: Commentary and Documents, Boston: World Peace Foundation, 1946, p. 62.

$7^{6}$ 'Report of the International Committee of Jurists entrusted by the Council of the League of Nations with the task of giving an advisory opinion on the legal aspects of Aaland Islands question, League of Nations', Official Journal, Special Supplement, No. 3, October 1920 , p. 5 . 
a right to secession (or indeed any other right) is a matter wholly within the domestic jurisdiction of the territorial State."77

States viewed domestic jurisdiction as corollary of the sovereignty of States. ${ }^{78}$ As such, domestic jurisdiction embraces all matters subject to domestic jurisdiction and national legal order, including questions relating to economic and social development, boundaries (internal and external), to name a few. As far as human rights are concerned, the general view is that the Charter human rights provisions should be given effect within the domestic constitutional processes of States through implementing legislation. ${ }^{79}$ The final report of Committee III, tasked, inter alia, to draft Chapter IX on economic and social cooperation (which contained human rights provisions and referred to selfdetermination) specifically underlined that “...nothing contained in Chapter IX can be construed as giving authority to the Organisation to intervene in the domestic affairs of states." ${ }^{80}$ B. Schlüter argued, in that regard, that " $[t]$ he legal protection of substantive rights derived from the Charter would entirely depend on, and be limited by, the procedures of national law." ${ }^{81}$ The same idea is embedded in almost every international human rights instrument, including the International Covenants on human rights (see below). ${ }^{82}$

77 M. Koskenniemi, 'National Self-Determination Today: Problems of Legal Theory and Practice', in The International and Comparative Law Quarterly, 1994, no. 2, p. 247, (Emphasis original).

78 Doc. 976, I/1/40, June 14, U.N.C.I.o. Documents, vol. vi, p. 495; P. Lauren, 'First Principles of Racial Equality: History and the Politics and Diplomacy of Human Rights Provisions in the United Nations Charter', in Human Rights Quarterly, 1983, no. 1, pp. 19, 23.

79 A. Bayefsky and J. Fitzpatrick, 'International Human Rights Law in United States Courts: A Comparative Perspective', in Michigan Journal of International Law, 1992, no. 1, pp. 44-45; J. Southard, 'Human Rights Provisions of the U.N. Charter: The History in U.s. Courts', in ILSA Journal of International and Comparative Law, 1995, no. 1, p. 45; M. Neal, 'The United Nations and Human Rights', in International Conciliation, 1953-1955, no. 113, pp. 143-144, 146; L. Gross, 'The Impact of the United Nations upon Domestic Jurisdiction', in Department of State Bulletin, 1948, no. 263, p. 262.

80 Doc. 924, II/12, June 12, U.N.C.I.o. Documents, vol. viII, p. 81; Doc. 1144, II/16, June 21, U.N.C.I.o. Documents, vol. viII, p. 129; Doc. 567, II/3/27, May 25, U.N.C.I.o. Documents, vol. X, p. 83; Doc. 1115, II/4/44 (1) (a), June 20, U.N.C.I.O. Documents, vol. X, p. 622.

81 B. Schlüter, 'The Domestic Status of the Human Rights Clauses of the United Nations Charter', in California Law Review, 1973, no. 1, pp. 112-113. On this point, see also 'Judicial Enforcement of International Law against the Federal and State Governments', in Harvard Law Review, 1991, no. 6, pp. 1269-1288.

82 International Covenant on Economic, Social and Cultural Rights, adopted by the U.N. General Assembly on 16 December 1966, United Nations Treaty Series, vol. 993, I-14531, 
A Special Rapporteur of the Sub-Commission on the Prevention Discrimination and the Protection of Minorities Aureliu Cristescu succinctly summarised the general view on this subject, arguing that:

[t] he principle of equal rights and self-determination, as laid down in the Charter of the United Nations, does not grant an unlimited right of secession to populations living in the territory of an independent sovereign State, and such a right cannot be regarded as a provision of lex lata. A right of secession supported or encouraged by foreign States would clearly be in glaring contradiction with the respect for territorial integrity on which the principle of sovereign equality of States is based. It would be dangerous to recognize in international law a general and unlimited right of secession, for the rights of a population living in the territory of a given State are governed by the national constitutional law of that State. ${ }^{83}$

Thus being said, the exercise of self-determination, as a variant of human rights, should be without prejudice to the sovereignty of States, and by implication to their territorial integrity, and should be given effect within the constitutional and legal framework of a State. ${ }^{84}$ The discussions in San Francisco showed that States put strong emphasis on respecting their sovereignty and political independence, non-interference into matters falling within their

4-12; International Covenant on Civil and Political Rights, adopted on 19 December 1966, United Nations Treaty Series, vol. 999, I-14668, 172-186.

83 A. Cristescu, Special Rapporteur of the Sub-Commission on the Prevention of Discrimination and Protection of Minorities, 'The right to self-determination: historical and current development on the basis of United Nations instruments', United Nations: New York, 1981, UN Doc. E/CN.4/Sub.2/404/Rev.1, para. 173 .

84 On this point, see Judgment of the Supreme Court of Canada, Reference re Secession of Quebec, [1998] 2 S.C.R. 217, 20 August 1998, available at <https://scc-csc.lexum.com/scccsc/scc-csc/en/1643/1/document.do >; Judgment of the Constitutional Court of Spain on the law on 'Juridical Transition and founding of the Republic' passed by the Parliament of Catalonia on 8 September 2017, 8 November 2017, available in English at <https://www. tribunalconstitucional.es/ResolucionesTraducidas/Ley\%2otransitoriedad\%2oENGLISH. pdf $>$; See also M.N. Shaw, 'Peoples Territorialism and Boundaries', in European Journal of International Law, 1997, no. 3, pp. 479, 483-487; V. Van Dyke, 'Self-Determination and Minority Rights', in International Studies Quarterly, 1969, no. 3, p. 239; L. Green, W. Reisman, \& R. Ramazani, 'Self-Determination and Settlement of the Arab-Israeli Conflict', in The American Journal of International Law, 1971, no. 4, pp. 41, 46. 
domestic jurisdiction. Not only they did not interpret self-determination as granting the right to secede, many delegations opposed such a notion.

\section{Subsequent Developments in Law and Practice}

At a time of negotiation of the Charter self-determination was not considered a legal concept, nor had it been developed as a general principle of international law with criteria and standards of its application. ${ }^{85}$ In the years after the adoption of the Charter, the principle of self-determination was generally referred to in relation to the dependent peoples and populations of colonies and non-self-governing territories. ${ }^{86}$ The debate in the U.N. General Assembly in the following decades and the adopted resolutions solidified practical implementation of this principle within that meaning. ${ }^{87}$

The scope of application of this principle was further clarified with its development beyond the colonial context with the adoption in 1966 of the International Covenant on Economic, Social and Cultural Rights ${ }^{88}$ and the

85 B. Rivlin, 'Self-Determination and Dependent Areas', in International Conciliation, 19531955, no. 193, p. 199; M. Nawaz, 'The Meaning and Range of the Principle of Self-Determination', in Duke Law Journal, 1965, no. 1, pp. 92-93.

86 J. Wilson, 'The Applicability of the Principle of Self-Determination to the Trust Territory of the Pacific Islands', in The American Journal of International Law, 1973, no. 5, pp. 24-25; V. Van Dyke, 'Self-Determination and Minority Rights', in International Studies Quarterly, 1969, no. 3, pp. 229, 235; C. Eagleton, 'The United States and the United Nations', in Annual Survey of American Law, 1952, p. 19. For the views of the principal sponsor of this principle in the Charter - the Soviet Union - see E. Goodman, 'The Cry of National Liberation: Recent Soviet Attitudes Toward National Self-Determination', in International Organization, 1960, no. 1, pp. 92-106; B. Meissner, 'The Soviet Concept of Nation and the Right of National Self-Determination', in International Journal, 1976, no. 1, pp. 79-81.

87 "Declaration on the Granting of Independence to Colonial Countries and Peoples", U.N.G.A. Res. 1514 (XV), 14 December 196o; "Principles which should guide Members in determining whether or not an obligation exists to transmit the information called under Article 73 e of the Charter", U.N.G.A. Res. 1541 (xv) 15 December 196o, annex; The establishment and history of the Special Committee are covered in detail in Section II of the note by the U.N. Secretary-General A/AC.109/2018/L.1. See also the Report of the Special Committee for 2018, U.N. Doc. A/73/23; "Implementation of the Declaration on the Granting of Independence to Colonial Countries and Peoples", U.N.G.A. Res. 2105 (xx), 20 December 1965.

88 Adopted by the U.N. General Assembly on 16 December 1966, United Nations Treaty Series, Vol. 993, I-14531, pp. 4-12. 
International Covenant on Civil and Political Rights, ${ }^{89}$ which provide in Article 1 common to both instruments the identical provision on self-determination.

Although the provision of Article 1 refers to "all peoples" as having the right to self-determination, a considerable number of States, including those submitted the proposals, noted in the course of negotiations, that there was no right to secede. ${ }^{90}$ The following summary of the debate in the Third Committee is illustrative in that regard:

Much of the discussion on Article 1 ha related the question of selfdetermination to the colonial issue, but that was only because the peoples of Trust and Non-Self-Governing Territories had not yet attained independence. The right would be proclaimed in the covenants as a universal right and for all time. The dangers of including the article had been exaggerated. It was true that the right could and had been misused, but that did not invalidate it. It was said that the article was not concerned with minorities or the right of secession, and the terms 'peoples' and 'nations' were not intended to cover such questions. ${ }^{91}$

Both Covenants contain specific restrictive provisions. Thus, common Article 5.1 of the Covenants stipulates that "nothing in the present Covenant may be interpreted as implying for any State, group or person any right to engage in any activity or to perform any act aimed at the destruction of any of the rights or freedoms recognized herein, or at their limitation to a greater extent than is provided for in the present Covenant". ${ }^{22}$ According to Articles 24 and 25 of the International Covenant on Economic Social and Cultural Rights and Articles 46 and 47 of the International Covenant on Civil and Political Rights, "nothing in the present Covenant shall be interpreted as impairing the provisions of the Charter of the United Nations.....93

89 Adopted by the U.N. General Assembly on 19 December 1966, United Nations Treaty Series, Vol. 999, I-14668, pp. 172-186.

9o H. Quane, 'The United Nations and the Evolving Right to Self-Determination', in The International and Comparative Law Quarterly, 1998, no. 3, p. 56o and footnote 122.

91 Report of the Third Committee, U.N. Doc. A/3077, 8 December 1955, para. 39.

92 International Covenant on Economic, Social and Cultural Rights, United Nations Treaty Series, Vol. 993, I-14531, pp. 4-12, at p. 6; International Covenant on Civil and Political Rights, United Nations Treaty Series, Vol. 999, I-14668, pp. 172-186, at p. 174.

93 International Covenant on Economic, Social and Cultural Rights, United Nations Treaty Series, Vol. 993, I-14531, at p. 10; International Covenant on Civil and Political Rights, United Nations Treaty Series, at pp. 184-185. 
In its General Comment 12 concerning the reporting obligations of States parties with regard to Article 1, paragraph 1, of the International Covenant on Civil and Political Rights, the Human Rights Committee, acting under the Covenant as its monitoring body, noted that States parties "should describe the constitutional and political processes which in practice allow the exercise of this right", 94 thus confirming that its realisation should take place within constitutional and legal frameworks of States.

The Human Rights Committee further noted that positive action by States to facilitate realization of and respect for the right of peoples to self-determination "must be consistent with the States' obligations under the Charter of the United Nations and under international law: in particular States must refrain from interfering in the internal affairs of other States and thereby adversely affecting the exercise of the right to self-determination". ${ }^{95}$

In its subsequent practice, the Human Rights Committee confirmed also that self-determination was not concerned with minorities or the right of secession. Thus, insofar as the International Covenant on Civil and Political Rights contains both the terms "peoples" and "minorities", in its General Comment 23, the Committee drew a clear distinction between the right to self-determination set forth in Article 1 and the rights of persons belonging to minorities protected under Article 27 of the Covenant:

The former is expressed to be a right belonging to peoples and is dealt with in a separate part (Part I) of the Covenant. Self-determination is not a right cognizable under the Optional Protocol. Article 27, on the other hand, relates to rights conferred on individuals as such and is included, like the articles relating to other personal rights conferred on individuals, in Part III of the Covenant and is cognizable under the Optional Protocol. 96

The Committee particularly emphasized that "the enjoyment of the rights to which Article 27 relates does not prejudice the sovereignty and territorial

94 Compilation of General Comments and General Recommendations Adopted by Human Rights Treaty Bodies, Twenty-first session (1984), H.R.C. General Comment 12: Article 1 (Right to self-determination), U.N. Doc. HRI/GEN/1/Rev.8, 8 May 2006, pp. 173-174, at p. 173 , para. 4 .

95 Ibid., para. 6.

96 Compilation of General Comments and General Recommendations Adopted by Human Rights Treaty Bodies, Twenty-first session (1984), H.R.C., Fiftieth session, 1994, H.R.C. General Comment 23: Article 27 (Rights of minorities), U.N. Doc. HRI/GEN/1/Rev.8, 8 May 2006, pp. 197-200, at p. 198, para.3.1. 
integrity of a State party". ${ }^{97}$ This position has been confirmed by the jurisprudence of the Human Rights Committee, which has chosen a strict interpretation whereby Article 1 cannot be invoked by individuals. ${ }^{98}$

Héctor Gros Espiell, Special Rapporteur of the Sub-Commission on Prevention of Discrimination and Protection of Minorities, concluded that " $[t]$ he right to secession from an existing State Member of the United Nations does not exist as such in the instruments or in the practice followed by the Organization, since to seek to invoke it in order to disrupt the national unity and the territorial integrity of a State would be a misapplication of the principle of self-determination contrary to the purposes of the United Nations Charter".99

Another Special Rapporteur of the same Sub-Commission, Aureliu Critescu, also believed that "the application of the principle [of self-determination] to all peoples should not be interpreted as an encouragement to secessionist or irredentist movements, or as justifying activities aimed at changing a country's system of government". ${ }^{100}$

In 1970, the U.N. General Assembly adopted the Declaration on Principles of International Law concerning Friendly Relations and Cooperation among States in accordance with the Charter of the United Nations, which, among other principles, contains eight paragraphs under the heading "The principle of equal rights and self-determination of peoples".101

The most controversial provision of the Declaration is what is referred to in the scholarly research as the so-called "safeguard" or "remedial secession" clause. It states that nothing in the section on self-determination "shall be construed as authorizing or encouraging any action which would dismember or impair, totally or in part, the territorial integrity or political unity of sovereign and independent States conducting themselves in compliance with the principle of equal rights and self-determination of peoples as described above and

97 Ibid., para. 3.2.

98 See A. Cassese, Self-determination of peoples. A legal reappraisal, Cambridge: Cambridge University Press, 1995, pp. 142-143; S. Joseph, M. Castan, The International Covenant on Civil and Political Rights. Cases, Materials, and Commentary. Oxford: Oxford University Press, 2013, $3^{\text {rd }}$ ed., pp. 153-165.

99 H. Gros Espiell, 'The right to self-determination: implementation of United Nations resolutions', United Nations: New York, 1980. U.N. Doc. E/CN.4/Sub.2/405/Rev.1 (1980), para. 90.

100 A. Critescu, 'The right to self-determination: historical and current development on the basis of United Nations instruments', United Nations: New York, 1981. U.N. Doc. E/CN.4/ Sub.2/404/Rev.1, para. 268.

101 U.N.G.A. Res. 2625 (XXV), 24 October 1970, annex. 
thus possessed of a government representing the whole people belonging to the territory without distinction as to race, creed or colour".102

Some authors, although with caution, argue that it is not entirely excluded that a right of secession may exist in extreme cases of oppression and discrimination, and that the said clause in the Declaration on Principles recognizes this, even if indirectly. ${ }^{103}$

However, although disagreements during the negotiations on the provisions in question prevented the achievement of a common understanding and some States indeed favoured universal or general application of selfdetermination, ${ }^{104}$ the majority of delegations nevertheless perceived the principle either within the context of decolonization or in a broader sense of alien subjugation, domination or exploitation. ${ }^{105}$

As the authoritative commentary to the U.N. Charter summarizes:

The anti-colonial orientation of these formulations is beyond any doubt colonialism must find its end, but the 'newly independent States' should be protected in their territorial integrity and political independence. Only in cases of discriminatory, racist regimes where a part of the population denies the rest of the people any political participation and full citizenship rights might a denial of the respect for political independence and

102 Ibid., para. 7.

103 See e.g. R. Rosenstock, 'The Declaration of Principles of International Law Concerning Friendly Relations: A Survey', in American Journal of International Law, 1971, no. 5, p. 732; A. Cassese, Self-determination of peoples. A legal reappraisal, Cambridge: Cambridge University Press, 1995, p. 118; G. Nolte, 'Secession and external intervention', in M. Kohen (ed.), Secession. International Law Perspectives. Cambridge: Cambridge University, 20o6, p. 85; J. Dugard, D. Raič, 'The role of recognition in the law and practice of secession', in M. Kohen (ed.), ibid., p. 103; J. Crawford, The Creation of States in International Law, Oxford: Clarendon Press, 2006, $2^{\text {nd }}$ ed., p. 119; S. Sheeran, 'International Law, Peace Agreements and Self-Determination: The Case of the Sudan', in The International and Comparative Law Quarterly, 2011, no. 2, pp. 451, 452.

104 Statements by members of the Special Committee at the concluding stage of the Special Committee's session. Report of the Special Committee on Principles of International Law Concerning Friendly Relations and Co-operation among States. U.N. Doc. A/8018, 1970. See statements by Italy, France, Canada, Australia, U.K., U.s.A., pp. 88, 91, 98, 104, 114, 122, paras. 140, 150, 173, 202. 233, 265 .

105 Ibid., see statements by U.s.s.R., Argentina, Venezuela, Romania, Cameroon, Poland, Nigeria, Madagascar, Czechoslovakia, Syria, India, U.A.E., pp. 72-73, 75-77, 79, 82, 94, 100, 100-101, 101-102, 102-103, 105, 110, 116, paras. 91-92, 94, 105, 107, 115, 123, 160-162, 179-180, 183, $189,193,197,206,218,243$. 
territorial integrity be justified (the last part of the formula cited above must be understood as a reaction to the problem of 'apartheid'). ${ }^{106}$

Although the aforementioned "safeguard clause" has been reiterated, in slightly different language, in some subsequent international documents, ${ }^{107}$ the focus on self-determination within decolonization and illegal occupation has prevailed. ${ }^{108}$ This testifies to the achievement of reasonable consistency over the sufficiently long time, whereas nothing confirms the existence of international practice demonstrating the unequivocal and overwhelming acceptance of the so-called right of remedial secession, whether in general terms or with regard to specific situations. ${ }^{109}$

Thus, the right to self-determination as applying to peoples which remain under colonial domination and foreign occupation has been reaffirmed in the 1977 Additional Protocol I to the Geneva Conventions of 1949 , $^{110}$ as well as in numerous United Nations resolutions, including those adopted at the level of the Heads of State and Government. Among them are the U.N. Millennium Declaration, ${ }^{111}$ the World Summit Outcome, ${ }^{112}$ the outcome document of the U.N. Conference on Sustainable Development, entitled "The future we want",113 and the outcome document of the U.N. summit for the adoption of the post2015 development agenda, entitled "Transforming our world: the 2030 Agenda

106 B. Simma, D.-E. Khan, G. Nolte, A. Paulus, (ed.), The Charter of the United Nations. A Commentary, Oxford: Oxford University Press, 2012, $3^{\text {rd }}$ ed, vol. I, p. 321.

107 Vienna Declaration and Programme of Action, World Conference on Human Rights. U.N. Doc. A/CONF.157/23, 25 June 1993, para. 2; Declaration on the Occasion of the Fiftieth Anniversary of the United Nations. U.N.G.A. Res. 50/6, 9 November 1995, para. 1; Report of the World Summit on Sustainable Development, Johannesburg, South Africa, $26 \mathrm{Au}-$ gust-4 September 2002. Plan of Implementation of the World Summit on Sustainable Development. Un. Doc. A/CONF.199/20*, paras. 103-104.

108 See M.N. Shaw, 'Peoples, Territorialism and Boundaries', in European Journal of International Law, 1997, no. 3, pp. 478-507, at pp. 482-483.

109 M.N. Shaw, International Law, Cambridge: Cambridge University Press, 2017, $8^{\text {th }}$ ed., p. 203 .

110 Protocol additional to the Geneva Conventions of 12 August 1949, and relating to the protection of victims of international armed conflicts (Protocol I) (with annexes, Final Act of the Diplomatic Conference on the reaffirmation and development of international humanitarian law applicable in armed conflicts dated 10 June 1977 and resolutions adopted at the fourth session). Adopted at Geneva on 8 June 1977. For text, see United Nations Treaty Series, Vol. 1125, I-17512, pp. 4-545, at p. 7 .

111 U.N.G.A. Res. 55/2, 8 September 2000, para. 4.

112 U.N.G.A. Res. 6o/1, 16 September 2005, para. 5 .

113 U.N.G.A. Res. 66/288, 27 July 2012, annex, para. 27. 
for Sustainable Development".114 The latest example is the Political Declaration adopted by the U.N. General Assembly at the Nelson Mandela Peace Summit on 24 September 2018. ${ }^{115}$ All these documents were adopted unanimously.

The only document on self-determination regularly adopted within the United Nations is the annual resolution of the Third Committee of the General Assembly on the universal realization of the right of peoples to selfdetermination. The resolution makes particular focus on the situations of peoples under colonial, foreign and alien domination resulting from "acts of foreign military intervention, aggression and occupation", regards such acts as leading to the suppression of the right of peoples to self-determination and other human rights and, in this regard, calls upon those States responsible to cease immediately their military intervention in and occupation of foreign countries and territories. ${ }^{116}$

The U.N. Security Council in its practice has considered self-determination in the context of either colonial and non-self-governing territories ${ }^{117}$ or its application by the parties concerned, with their unquestionable consent, as an appropriate solution. ${ }^{118}$

For the purpose of this article, it is worth noting that due to controversy surrounding the interpretation of the "safeguard clause", the 1970 Declaration was not accepted as a source of reiteration of this clause in the relevant regional documents, including the 1975 CSCE Helsinki Final Act. The principles of the Final Act, including in particular that of equal rights and self-determination of peoples, were drafted in such a way as to emphasize the norm of territorial

114 U.N.G.A. Res. 70/1, 25 September 2015, para. 35 .

115 U.N.G.A. Res. 73/1, para. 6.

116 'Universal realization of the right of peoples to self-determination', U.N.G.A. Res. 72/159, 19 December 2017. See also the Reports of the U.N. Secretary-General, 'Right of peoples to self-determination', U.N. Doc. A/73/329, 20 August 2018, and 'Use of mercenaries as a means of violating human rights and impeding the exercise of the right of peoples to selfdetermination', U.N. Doc. A/73/303, 6 August 2018; 'Strengthening the role of mediation in the peaceful settlement of disputes, conflict prevention and resolution', U.N.G.A. resolutions $65 / 283$ of 22 June 2011, preamble para. 5 ; 68/303 of 31 July 2014, preamble para. 8; and 70/304 of 9 September 2016, preamble para. 7 .

117 For the U.N.s.c. practice, see Repertoire of the Practice of the Security Council, Consideration of the provisions of Article 1, Paragraph 2 of the Charter, in the period of 1959-1999, available at $<$ https://www.un.org/en/sc/repertoire/principles.shtml\#relı.

118 See the Statement issued by the President of the U.N. Security Council in connection with the results of the referendum on self-determination held on 7 February 2011 in South Sudan. S/PRST/2011/3, 9 February 2011. In that statement, the Security Council made it clear that the process mandated by the Comprehensive Peace Agreement "represents an exceptional case and does not by itself set a precedent", ibid., para. 5 . 
integrity of States and inviolability of their frontiers. Furthermore, not only the realization of the principle of equal rights and self-determination of peoples, as set forth in the Final Act, cannot violate the territorial integrity, inviolability of frontiers and unity of States, but any exercise of this principle cannot contradict the requirement of consent of the participating State concerned for any border changes or modifications. Clearly, the drafters of the Final Act did not view the self-determination principle as granting a right of unilateral secession. The practice of States in applying the Helsinki Final Act principles over the period passed since then and the subsequent decisions and documents adopted within the CSCE/OSCE framework suggest that this position has not been affected by the changed circumstances and political developments on the European continent. ${ }^{119}$ The principle of equal rights and self-determination of peoples is not interpreted as a right of secession forty-three years after the signing of the Final Act, specifically in the context of the protracted conflicts in the OSCE area. ${ }^{120}$

The right to self-determination has also been referred to in the jurisprudence of the International Court of Justice (I.C.J.). ${ }^{121}$ In its advisory opinion on Kosovo - the most recent pronouncement by the I.C.J. on the subject under consideration, ${ }^{122}$ the Court concluded by a clear majority that "general

119 See Concluding Document of the Vienna Meeting 1986 of Representatives of the participating States of the Conference on Security and Co-operation in Europe, held on the basis of the provisions of the Final Act Relating to the Follow-up to the Conference, 1989, para 5, pp. 4-5, available at <https://www.osce.org/mc/40881>; Charter of Paris for a New Europe, adopted at the Second CSCE Summit of Heads of State or Government, Paris, 19-21 November 1990, p. 5, available at <https://www.osce.org/mc/39516>.

120 R. Sadigbayli, 'Codification of the inviolability of frontiers principle in the Helsinki Final Act: Its purpose and implications for conflict resolution', in Security and Human Rights, 2013, no. 24, pp. 338, 400-410.

121 Legal Consequences for States of the Continued Presence of South Africa in Namibia (South West Africa) notwithstanding Security Council Resolution 276 (1970), Advisory Opinion. I.C.J. Reports 1971, paras. 52-53; Western Sahara, Advisory Opinion. I.C.J. Reports 1975; Frontier Dispute (Burkina Faso v Republic of Mali), Judgment. I.C.J. Reports 1986; East Timor (Portugal v. Australia), Judgment. I.C.J. Reports 1995, para. 29; Legal Consequences of the Construction of a Wall in the Occupied Palestinian Territory, Advisory Opinion. I.C.J. Reports 2004, para. 88; Accordance with international law of the unilateral declaration of independence in respect of Kosovo, Advisory Opinion. I.C.J. Reports 2010, paras. 79, 82, 83 .

122 On 17 February 2008, Kosovo, with a majority ethnic Albanian population, unilaterally declared its independence from the Republic of Serbia. On 22 July 2010, in response to the request contained in U.N. General Assembly resolution 63/38 of 8 October 2008, the International Court of Justice rendered its advisory opinion on Accordance with international law of the unilateral declaration of independence in respect of Kosovo. 
international law contains no applicable prohibition of declarations of independence"123 and, accordingly, that "the adoption of the declaration of independence of 17 February 2008 did not violate general international law, Security Council resolution 1244 (1999) or the Constitutional Framework".124

However, the advisory opinion is disappointing not only for Serbia, which initiated the Court proceedings, but also for those interpreting the Kosovo situation as having established the legal grounds and successful precedent of unilateral secession from existing sovereign States. The following points need to be made in relation to this advisory opinion.

First, the I.C.J. reaffirmed the validity of the right to self-determination in the context of independence with regard to (a) peoples of non-self-governing territories and (b) peoples subject to alien subjugation, domination and exploitation. ${ }^{125}$

Second, the Court refrained from taking a position on "whether ... international law of self-determination confers upon part of the population of an existing State a right to separate from that State" and "whether international law provides for a right of 'remedial secession.'"126 Nevertheless, the Court noted that radically different views exist on this subject - a significant determination confirming that there is no evidence of State practice and opinio juris pointing to the emergence of such a right under international law.

Third, the Court refrained also from clarifying its position on whether the declaration in question was in accordance with international law. In effect, this position of the Court has not introduced any novelty into the theory and practice of international law. ${ }^{127}$

123 Accordance with international law of the unilateral declaration of independence in respect of Kosovo, Advisory Opinion. I.C.J. Reports 2010, para. 84.

124 Ibid., para. 122.

125 Accordance with international law of the unilateral declaration of independence in respect of Kosovo, Advisory Opinion. I.C.J. Reports 2010, para. 79.

126 Ibid., paras. 82-83.

127 See e.g. M.N. Shaw, Title to Territory in Africa: International Legal Issues, Oxford: Clarendon Press, 1986, p. 215; Report by J. Crawford: 'Response to Experts Reports of the Amicus Curiae', in A. Bayefsky, Self-determination in International Law: Quebec and Lessons Learned, The Hague: Kluwer, 2000, pp. 157-158, para. 6; Report by A. Pellet: 'Legal Opinion on Certain Questions of International Law Raised by the Reference', in A. Bayefsky, (2000), p. 98; Report by George Abi-Saab: 'The Effectivity Required of an Entity that Declares its Independence in Order for it to be Considered a State in International Law', in A. Bayefsky (2000), p. 73; Report by T. Franck: 'Opinion Directed at Question 2 of the Reference', in A. Bayefsky (2000), pp. 77-79; F. Postmodern, 'Tribalism and the Right to Secession', in C. Brölmann, R. Lefeber, M. Zieck, (eds.), Peoples and Minorities in International Law, 
Most importantly, by referring to the contemporaneous practice of the U.N. Security Council, the Court pointed out that some unilateral declarations of independence had been, in the past, specifically repudiated by the Security Council on the grounds that "the illegality attached to the declarations of independence ... stemmed not from the unilateral character of these declarations as such, but from the fact that they were, or would have been, connected with the unlawful use of force or other egregious violations of norms of general international law, in particular those of a peremptory character (jus cogens)".128

Although, by referring to several participants of deliberations, the Court mentioned some Security Council resolutions, ${ }^{129}$ the list of the situations amounting to its determination of illegality is definitely not exhaustive. ${ }^{130}$ With regard to the protracted conflicts in the OSCE area, the international community has consistently rejected the secessionist claims and applied a policy of collective non-recognition of the secessionist entities.

Thus, for example, in its relevant resolutions on the conflict in and around the Nagorno-Karabakh region of Azerbaijan, the U.N. Security Council condemned the use of force against Azerbaijan and the bombardment and occupation of its territories and reaffirmed respect for the sovereignty and territorial integrity of Azerbaijan, the inviolability of international borders and the inadmissibility of the use of force for the acquisition of territory. In response to territorial claims and forcible actions, the Council reconfirmed that the Nagorno-Karabakh region is a part of Azerbaijan and demanded the immediate, complete and unconditional withdrawal of the occupying forces from all the occupied territories. ${ }^{131} \mathrm{~A}$ declaration approved on 4 November

Dordrecht: Martinus Nijhoff, 1993, p. 12; A. Pellet, 'Kosovo-The Question Not Asked. SelfDetermination, Secession, and Recognition', in M. Milanović, M. Wood, (ed.), The Law and Politics of the Kosovo Advisory Opinion, Oxford: Oxford University Press, 2015, pp. 273-277.

128 Accordance with international law of the unilateral declaration of independence in respect of Kosovo, Advisory Opinion, I.C.J. Reports 2010, para. 81.

129 U.N.S.C. resolutions 216 (1965), 217 (1965), 541 (1983) and 787 (1992).

130 See e.g. J. Crawford, The Creation of States in International Law, Oxford: Clarendon Press, 2006, $2^{\text {nd }}$ ed., pp. 131-134.

131 U.N.S.C. resolutions 822 (1993), 853 (1993), 874 (1993) and 884 (1993). See also the Report by M.N. Shaw 'Fundamental norm of the territorial integrity of States and the right to self-determination in the light of Armenia's revisionist claims', U.N. Doc. A/63/664S/2008/823, 29 December 2008; and the Report by A. Pellet: 'Legal opinion on third party obligations with respect to illegal economic and other activities in the occupied territories of Azerbaijan', U.N. Doc. A/71/880-S/2017/316*, 26 April 2017. 
1993 by the nine countries of the CSCE Minsk Group, ${ }^{132}$ concerning the developments in the conflict on the ground, stated that "No acquisition of territory by force can be recognized, and the occupation of territory cannot be used to obtain international recognition or to impose a change of legal status", which is illustrative of the policy of non-recognition. ${ }^{133}$

With regard to the conflict in Abkhazia, Georgia, the U.N. Security Council affirmed the sovereignty and territorial integrity of Georgia, called to refrain from use of force and expressed concern at reports of "ethnic cleansing" and other serious violations of international humanitarian law. ${ }^{134}$

In its resolution entitled "Territorial integrity of Ukraine", the U.N. General Assembly affirmed its commitment to the sovereignty and territorial integrity of Ukraine, noting, inter alia, that the territory of a State shall not be the object of acquisition by another State resulting from the threat or use of force, and that any attempt aimed at the partial or total disruption of the national unity and territorial integrity of a State or country or at its political independence is incompatible with the purposes and principles of the Charter. ${ }^{135}$

The Ministers for Foreign Affairs of the OSCE participating States in their statement adopted at the 2017 Ministerial Council Meeting in Vienna reiterated their strong resolve to attain a comprehensive, peaceful and sustainable settlement of the Transdniestrian conflict based on the sovereignty and territorial integrity of the Republic of Moldova within its internationally recognized borders with a special status for Transdniestria. ${ }^{136}$

That the application of the principle of equal rights and self-determination of peoples in the context of protracted conflicts does not imply secession follows from a statement made by the OSCE Chairman-in-Office at the OSCE Lisbon Summit of 1996, in which all osCE participating States except Armenia expressed their support for the principles that should form part of the settlement of the conflict, including the territorial integrity of Armenia and Azerbaijan and the highest degree of self-rule for Nagorno-Karabakh within

132 See oscE. Activities regarding the Conflict dealt with by the Minsk Conference, Survey of osce Field Operations, OSCE Doc. SEC.GAL/110/18, 25 June 2018, pp. 43-45, <https://www. osce.org $/ \mathrm{cpc} / 74783$ ?download=true $>$.

133 See U.N. Doc. S/26718, Enclosure I. Emphasis added.

134 U.N.s.C. resolutions 881 (1993) and 876 (1993).

135 U.N.G.A. resolution 68/262, 27 March 2014.

${ }_{13}$ Ministerial Statement on the Negotiations on the Transdniestrian Settlement Process in the " 5 +2" Format, Vienna, 8 December 2017, <https://www.osce.org/chairmanship/36158 6 ?download=true $>$. See also the Report by C. J. Borgen 'Thawing a Frozen Conflict: Legal Aspects of the Separatist Crisis in Moldova', Executive Summary, U.N. Doc. A/61/364, 20 September 2006 . 
Azerbaijan. ${ }^{137}$ In their subsequent statements regarding the conflict settlement principles, the Co-Chairmen of the OSCE Minsk Group have consistently referred to the core principles of the 1975 Helsinki Final Act, including the nonuse of force or threat of force, territorial integrity, and the equal rights and selfdetermination of peoples. ${ }^{138}$ It is worth recalling that the Final Act commits the participating States to "respect the equal rights of peoples and their right to self-determination, acting at all times in conformity with the purposes and principles of the Charter of the United Nations and with the relevant norms of international law, including those relating to territorial integrity of States".139 Similarly, the principle of non-use of force is linked in the Helsinki Final Act to the inadmissibility of changing the boundaries of States through use of force and together with other relevant provisions of the Final Act implies prohibition on the acquisition of territory by force and non-recognition of such unlawful situations. ${ }^{140}$

The Independent International Fact-Finding Mission led by H. Tagliavini, having reviewed the applicable Helsinki Final Act principles in the context of the conflict in Georgia in 2008, concluded that the realization of the principle of self-determination beyond its internal aspect within the framework of a State would make the Helsinki Final Act principles incompatible. ${ }^{141}$

To summarize the developments after the adoption of the Charter of the United Nations: First, the right of self-determination has been widely recognized as applying to the peoples of non-self-governing territories and to the peoples subjected to alien subjugation, domination and exploitation, including those under foreign military occupation. The realization by these categories of peoples of their right to self-determination may result in independence, integration or free association with another State or any other political status freely decided upon by the people concerned. Second, neither the provisions on self-determination in various international documents, nor State practice

137 See Fifth osce Summit of Heads of State or Government, Lisbon, 2-3 December 1996. Lisbon Summit Document, Annex 1, <https://www.osce.org/mc/39539>.

138 See e.g. Joint Statement by the Heads of Delegation of the osce Minsk Group Co-Chair Countries, Vienna, 7 December 2017, <https://www.osce.org/minsk-group/361286>.

139 Conference on Security and Cooperation in Europe, Final Act, Helsinki 1975, Declaration of Principles Guiding Relations between Participating States, Principle VIII "Equal rights and self-determination of peoples", para. 1, <https://www.osce.org/ helsinki-final-act?download=true $>$.

140 See R. Sadigbayli, Supra note 119 at 400-403.

141 See the Report by the Independent International Fact-Finding Mission on the Conflict in Georgia (IIFFMCG) based on the EU Council decision of 2 December 2008 (Council Decision 2008/901/CFSP), Vol. II, pp. 135-137. 
testify to the existence of the right to unilateral secession by national or ethnic minorities, including as a means of sanction or remedy. To hold otherwise would be tantamount to threatening the unity of all multinational societies and encouraging discrimination and intolerance on racial, ethnic and religious grounds. Third, self-determination has rather been recognized as applying to the peoples of independent States as a whole, including minority groups as part of their populations within those States, and provides for the right to choose their own form of government without external interference and participation in the conduct of public affairs at appropriate government levels. ${ }^{142}$ Finally, claims of self-determination are unsustainable when they are accompanied by violation of international law, including its peremptory norms (jus cogens), such as those prohibiting the threat or use of force against the sovereignty and territorial integrity of States.

\section{Concluding Remarks}

The discussions at the San Francisco Conference indicate that States did not recognise a right to unilateral secession of a part of population of a State as a means of exercising self-determination. The prevailing view at the Conference and in the years after the adoption of the U.N. Charter was that the beneficiaries of self-determination principle were populations in the colonies and non-selfgoverning territories who have not attained a full measure of self-government or small States subjugated to foreign domination and occupation. ${ }^{143}$

In accordance with the Charter, the territorial integrity of States is protected explicitly under the legal prohibition of the use of force and implicitly under the principle of sovereign equality and requirement to settle international disputes in conformity with the principles of justice and international law as well as principle 2(7) on non-intervention in matters which are within the domestic jurisdiction of States. It is indeed inconceivable that many States, who were advocating for inclusion of guarantees for respect of territorial integrity into the Charter and vigorously objected to a notion that self-determination might imply a right to secession, would submit to a legally-binding obligation under

142 See e.g. Compilation of General Comments and General Recommendations Adopted by Human Rights Treaty Bodies, Forty-eighth session (1996), C.E.R.D. General Recommendation XXI on the right to self-determination, U.N. Doc. HRI/GEN/1/Rev.8, 8 May 2006, pp. 253-254, para. 4.

143 R. Russell, A History of the United Nations Charter: The Role of the United States 1940-1945, Washington, D.C.: Brookings Institution, 1958, pp. 42-43. 
the Charter to grant, at least theoretically, a possibility for unilateral secession of a part of their territory. ${ }^{144}$

Most importantly, the principle of self-determination was considered by the drafters in function of other provisions. Interpretation of the principle as authorising unilateral secession and dismemberment of States that will inevitably lead to conflict and instability is incompatible with the overarching purpose of the Charter to develop friendly relations and maintain international peace and security. The view that maintenance of world peace is one of the overriding considerations to which the practical application of the principle of self-determination should be subordinated was expressed by the members of the Commission on Human Rights tasked to draft the International Covenants. ${ }^{145}$

The notion that the principle of self-determination granted the right to unilateral secession found no support in the subsequent international practice. Rather, self-determination is often used to serve political goals, with only few States interpreting it as such. ${ }^{146}$ Attempts to broaden the scope of selfdetermination have been consistently and overwhelmingly opposed by the international community, evidenced, on the one hand, in less ambiguous formulations adopted in international documents over the sufficiently long time, including at the highest political level, and in a series of unsuccessful secessionist attempts in various parts of the world, on the other.

Moreover, secessionist claims under whatever pretext, including the right to self-determination, accompanied by the use of force and other deplorable violations of international law, are generally viewed as null and void ab initio. Invalidation at the international level of secessionist claims and actions, collective non-recognition of the resulting situations and abstention from aid or

144 On this point see, for example, R. Emerson, 'Self-Determination', in The American Journal of International Law, 1971, no. 3, p. 464; M. Nawaz, 'The Meaning and Range of the Principle of Self-Determination', in Duke Law Journal, 1965, no. 1, p. 91.

145 Commission on Human Rights: Report of the $8^{\text {th }}$ session, 14 April-14 June 1952, U.N. Doc. E/2256, p. 4 .

146 J. Summers, 'The Rhetoric and Practice of Self-Determination: A Right of All Peoples or Political Institutions?', in Nordic Journal of International Law, 2004, no. 73; C.J. Borgen, 'Law, Rhetoric, Strategy: Russia and Self-Determination before and after Crimea', in International Law Studies Series. Us Naval War College, 2015, No. 216; C.J. Borgen, 'The Language of Law and the Practice of Politics: Great Powers and the Rhetoric of Self-Determination in the Cases of Kosovo and South Ossetia', in Chicago Journal of International Law, 2009, No. 1; R. Mullerson, 'Precedents in the Mountains: On the Parallels and Uniqueness of the Cases of Kosovo, South Ossetia and Abkhazia', in Chinese Journal of International Law, 2009, No. 2. 
assistance that contributes to their consolidation are among legal and political consequences that have been applied and need to be consistently maintained with regard to the protracted conflicts in the OSCE area and their settlement processes. 